\title{
THE DEVELOPMENT AND INCIDENCE OF DELIVERED PRICING IN AMERICAN INDUSTRY
}

\author{
Vernon A. Mund* \\ I
}

Marketing Practices Prior to the Rise of Trusts and Mergers

\section{A. The F.O.B. Practice}

In the American economy open markets for the basic commodities developed both as voluntary centralizations of private dealers and as formally organized commodity exchanges. By 1860 the principal central markets for iron, steel, and the non-ferrous metals were located in New York, Philadelphia, Pittsburgh, Cincinnati, Cleveland, Chicago, and St. Louis. The task of distributing the metals was largely performed by dealers and jobbers (independent wholesale merchants) who maintained warehouse facilities in the central markets and also on land adjacent to the producing mills. These trade interests purchased commodities from nearby mills or from sources abroad for resale to consuming industries. The products purchased were either shipped directly from the producing mills to the fabricators or placed in storage to await the development of consumer buying.

Merchants and speculators in the central markets performed the useful service of accumulating inventories, at a time when consumer demands were declining, for sale again when business conditions improved. This activity, known as the "balance wheel" function, helped to provide a broad and continuous market for first hand producers and also helped to prevent sharp price declines when the consuming industries were not buying. Thereupon, when the demands of consuming industries revived, the accumulated stocks of merchants and speculators served as a counterbalance to check extreme price advances.

The usual practice followed by various trade interests in the sale of the basic commodities was to quote prices f.o.b. their warehouses in the central markets or f.o.b. the mill if direct delivery was made. ${ }^{1}$ If delivered prices were quoted, they were determined by taking the seller's f.o.b. mill or warehouse price and adding the actual freight from the shipping mill to the various destination points. In the

\$.B.A. 1928, M.B.A. 1929, University of Washington; Ph.D. 1932, Princeton University. Professor of Economics, University of Washington. Author, Open Markets: AN Essential of Free Enterprise (1948).

${ }^{2}$ See, for example, the trade papers of the period, as well as 2 V. S. Clark, History of ManufacTURE IN THE United States 288 (1929). F.o.b. mill pricing means free on board, that is, loaded on cars or trucks at the seller's mill or warehouse with all charges paid up to that point but not including insurance or freight beyond. An f.o.b. price is the price at the freight yard of the origin of shipment. C.i.f. pricing differs from f.o.b. mill pricing in that a c.i.f. price is a composite price which covers payment for three separate items: (I) the f.o.b. mill price or cost, (2) the actual insurance cost, and (3) the actual freight cost to a particular destination. A c.i.f. price always means a landed price at the destination point. 
Pittsburgh-Plus case, Henry P. Bope, an executive in the American Steel Corporation, testified that in the steel industry the general practice as late as 1880 was to quote prices f.o.b. the mills. "Each mill," he added, "was a law unto itself."

The f.o.b. mill prices of a given seller were also usually uniform to all buyers at the mill or warehouse at a given time. Trade journals and the newspapers provided a considerable amount of price publicity, and the very number of independent dealers, with supplies on hand in the central markets or in storage at or near the producing mills, usually made it impossible for a seller to make some buyers pay more than the "going" price to others. It is true that a locally separate mill sometimes charged nearby buyers more than it received on shipments to buyers in a central market. ${ }^{3}$ All of the available evidence, however, indicates that this exercise of local monopoly power was an exceptional practice and not the rule. The general pattern was one of f.o.b. mill pricing in which prices in the local markets and at points of production were less than in the central markets and at destination points by the actual cost of freight and handling charges.

\section{B. The Growth of Discriminatory Pricing}

The rapid extension of rail lines around 1860 , and the rise of towns and consuming points along the main transportation routes made it possible to build larger mills and smelters and to expand greatly the areas of practical shipment. Geographically separate mills, moreover, gradually learned by experience that profits could be enhanced by making direct sales to local buyers at high prices while cutting prices on sales in other areas to match or undercut the quotations of distant rivals. Under such conditions, f.o.b. mill pricing in certain basic industries began to give way to various forms of discriminatory pricing. In order to avoid the evils of local price cutting and also to enhance their profits, a number of regional groups turned to the formation of "pools," "associations," and "loose-knit combinations" through which prices were fixed by agreement.

Monopoly agreements had frequently been made in earlier years by local groups of producers. Such agreements, it appears, were based upon the charging of identical f.o.b. mill prices. When geographically separate mills, however, sought to act as one on price, there at once developed the problem of how all of them could quote identical prices at the important consuming points because geographic location gave certain mills a freight advantage over others. If each locally separate mill had adopted an identical f.o.b. mill price, those nearest to the consuming centers would have secured a major share of the business. The iron bar industry, consisting of a number of geographically separate producers, wrestled with this problem as early as I875. According to the American Manufacturer for May II, I875, "The meeting of the Western Iron Association last week was a most important one and was largely

\footnotetext{
${ }^{2}$ Federal Trade Comm'n v. United States Steel Corp., Docket No. 760,2 Statement of Case 639 (1924).

3 J. M. Swank, The Manufacture of Iron in All Ages i88 (1892), quoting Israel Acrelius, A History of New Sweden I69 (1874).
} 
attended. ... It was . . . agreed to require each firm in this association to deposit a specified sum of money ... to be used as a forfeit, in case the depositing firm is detected in cutting rates. The equalizing of railroad freights is in the hands of a committee who as yet have made no report." (Italics supplied.)

The trade journals of 1875 to 1880 indicate that several groups of locally separate steel mills seeking to avoid price competition experimented with various plans of zone prices and freight equalization. In I880 the four manufacturers of steel beams (the Carnegie Company in Pittsburgh and three others in Eastern Pennsylvania and New Jersey) formed an association for fixing prices and established Pittsburgh as the common base for quoting prices. ${ }^{4}$ This agreement on the part of the locally separate steel beam producers to quote the Pittsburgh price plus the rail freight from Pittsburgh to destination, regardless of the actual origin of shipments or the actual freight cost incurred, appears to have been the first use of the basing point system in the United States.

In 1894 the manufacturers of nails adopted the Pittsburgh-Plus formula for the pricing of their product. According to a report of the Federal Trade Commission, "Early prices [for nails] were made mill prices, but as the business developed, manufacturers of wire and cut nails based quotations on the price f.o.b. Pittsburgh, either in carload or less than carload lots. That price at all other points was the same, with freight from Pittsburgh added."5

Pools, associations, and "loose-knit" combinations provided an effective means for avoiding price competition as long as business conditions were good. When demand began to decline, however, small and financially weak producers usually "broke away" and reduced their prices in order to find a selling outlet for their products. ${ }^{\circ}$ When the price agreements collapsed, competition typically became ruthless and cutthroat. The larger concerns, especially, cut prices sharply in areas of active competition in an effort to coerce or discipline firms showing a price independence. Such price cutting proved to be highly chaotic because the larger concerns could usually make up some or all of their losses elsewhere. The depression of $1896-1897$, it is reported, led to a collapse of all of the various pools and price associations, and the resulting price rivalries became particularly severe and demoralizing.

The weakness of pools, associations, and other forms of concerted action based upon agreement led business leaders and their legal counsel to search for more effective methods of price control. The trust device proved to be an effective method for controlling competitors and avoiding price competition, but its use was challenged and subsequently condemned in the state courts as a monopolistic measure. The revolutionary action taken by New Jersey in 1889 in providing that corporations

\footnotetext{
- Federal Trade Comm'n v. United States Steel Corporation, Docket No. 760,2 Statement of Case $638-639$ (1924).

EI $i d$. at 262-263. Additional data on the early use of the basing point system may be found in The Basing Point Problem 107-108 (TNEC Monograph 42, 194r).

- 13 Report of the Industrial Commission 501-502 (igor).
} 
chartered there could own and vote the stock of other corporations appeared to provide an effective substitute for the trust device, although the enactment of the Sherman Act in I890 raised doubts about the legality of this arrangement. These doubts, however, were largely dispelled by the Supreme Court in the Sugar Trust case, ${ }^{7}$ in which it was held that the Sherman Act could not be applied to a monopolistic combination of sugar refineries on the ground that manufacturing was distinct from commerce and that a combination of manufacturing plants had only an "indirect" effect upon commerce. Upon the basis of this decision, which the Court subsequently overruled, the way became clear for large business interests to form corporations to acquire a permanent and absolute ownership interest in scores of formerly independent and competing plants.

\section{II}

\section{Mergers and the Further Use of Geographic Price Discrimination}

\section{A. Cutthroat Competition}

Most of the new combinations (mergers) formed during the period 1897-1903, it appears, employed some form of geographic price discrimination in their pricing policies. In a number of cases, particularly in oil, tobacco, sugar, salt, copper, lead, iron, and steel, the combinations employed "local price cutting" in one area while maintaining prices elsewhere, expressly to injure or kill off a geographically separate competitor. This practice became known as "cutthroat competition." In Ig00 the United States Industrial Commission, after an extensive investigation of the methods of competition employed by the combinations, concluded that perhaps the "greatest evil" of combinations was to be found in the fact that they "cut prices to an unreasonable extent in certain localities, and even to individuals at certain times, for the sake of driving out their rivals."

The shocking use of local price cutting of the cutthroat variety was vividly revealed in the evidence presented in the Standard $O i l^{9}$ and American Tobacco ${ }^{10}$ cases decided by the Supreme Court in IgII. Upon the basis of this and other evidence, the House Committee on the Judiciary reported in 1914 as follows : ${ }^{11}$

In the past it has been a most common practice of great and powerful combinations engaged in commerce-notably the Standard Oil Co., and the American Tobacco Co., and others of less notoriety, but of great influence-to lower prices of their commodities, oftentimes below the cost of production in certain communities and sections where they had competition, with the intent to destroy and make unprofitable the business of their competitors, and with the ultimate purpose in view of thereby acquiring a monopoly in the particular locality or section in which the discriminating price is made.

Every concern that engages in this evil practice must of necessity recoup its losses in the particular communities or sections where their commodities are sold below cost or

\footnotetext{
${ }^{7}$ United States v. E. C. Knight Co., I56 U. S. I (1895).

8 I Report of the Industrial Commission 20 (I900).

- Standard Oil Co. of New Jersey v. United States, 22I U. S. I (IgrI).

"United States v. American Tobacco Co., 221 U. S. Io6 (I911).

$"$ H. R. Rep. No. 627, 63d Cong., 2d Sess. 8.9 (IgI4).
} 
without a fair profit by raising the price of this same class of commodities above their fair market value in other sections or communities.

Such a system or practice is so manifestly unfair and unjust, not only to competitors who are directly injured thereby but to the general public, that your committee is strongly of the opinion that the present antitrust laws ought to be supplemented by making this particular form of discrimination a specific offense under the law when practiced by those engaged in commerce.

\section{B. Sporadic or Anarchic Discrimination}

Some of the combinations were less ruthless in their pricing practices and adopted a moderate sort of discriminatory pricing "to meet competition." Products were usually sold f.o.b. the shipping mill, but at certain points in distant areas prices were cut to match or undercut somewhat the prices of a geographically separate rival. Various combinations found that a limited form of local price cutting was a profitable practice because it enabled them to avoid reducing prices in their area of freight advantage while "reaching out" to sell in distant regions. They also found that the practice was an advantageous method for checking the growth of distant rivals. When new competitors developed at certain points, delivered prices could be cut in those areas to prevent the rivals from becoming bigger and stronger competitors. This method of pricing appears to have been used by a number of combinations prior to the formal adoption of a policy of cooperative, systematic price discrimination.

Discriminatory price cutting to limit a competitor rather than to annihilate him has become known as "sporadic" or "anarchic" discrimination. The purpose of a dominant seller in employing this form of geographic price discrimination is largely opportunistic-that is, to charge high prices where competition is weak or nonexistent and to reduce delivered prices where rivals are active. The practice is unsystematic and anarchic, and discrimination is exercised in accordance with no principle except the ambiguous one of "meeting competition." A small producer can never be sure about the delivered price quotations which he is likely to find in his local area or the extent to which they may be cut.

\section{Cooperative, Systematic Price Discrimination}

The problem of formulating a price and sales policy for a considerable number of geographically separate mills in the iron and steel industry was squarely faced in IgOI by those in charge of the newly formed United States Steel Corporation-the largest and most extensive of the early mergers. If the Corporation had adopted identical f.o.b. mill prices at its separate mills, the unequal freight costs to consuming centers would have given certain mills a substantial sales advantage over others. The desire of the Corporation was to eliminate price competition among its constituent plants and at the same time permit considerable local autonomy in their management. Some method, therefore, had to be found for equalizing the element of freight. In discussing the adoption of the Pittsburgh-Plus system by the Corporation 
for use by its locally separate plants, Charles M. Schwab testified in rgor, "I don't see any other plan of doing it; you must establish some central point."12

The problem which a central financial unit has in unifying the sales policies of its constituent companies has been noted by a number of economic and legal authorities. Walter B. Wooden, a long-time student of basing point pricing, explains the situation as follows: "The full advantages of chain production are dependent upon the chain's maintenance of a system of pricing that reduces undue conflict between its own plants variously located. Such conflict would arise if the buyers were permitted to get their goods at a lower cost from one plant of the chain than from another. To permit that creates a tendency toward price competition among members of the family group that was established to avoid it."13

A further policy question before the Corporation was that of its relations with the remaining independents in the steel industry. There is abundant evidence to indicate that if one of the concerns in a sales area is a local enterprise while the other is a chain producer, geographic price discrimination tends to produce either (I) a condition of monopolistic exclusion or (2) a condition of cooperative, monopolistic pricing based upon conspiracy or price leadership and price following. If a local seller quotes a low price in his area of freight advantage, the multiple-plant company may retaliate and quote a lower discriminatory delivered price; and the resulting price cutting in that area may thereupon become cutthroat. The dominant concern is usually in a position to make up its losses elsewhere while the singleplant firm has no such opportunity. Inevitably, the local concern is faced with the prospect of being slowly or rapidly driven out of business or compelled to follow the price leadership of its more powerful rival. Historical records indicate that the Steel Corporation decided upon a monopoly policy of including its competitors rather than the usual one of excluding them, provided that they would follow its price leadership.

Thus it was that the regular and consistent use of the basing point formula by the United States Steel Corporation served the purposes (I) of insuring the quotation of identical prices by all mills-its own mills as well as independents-and (2) of avoiding the geographic and automatic allocation of sales which identical f.o.b. mill pricing would create. The prices announced by the Corporation at Pittsburgh became the "official" prices, and all producers quoted the Pittsburgh base prices plus the rail freight from Pittsburgh to the point of delivery regardless of their own individual location or the actual freight cost incurred. ${ }^{14}$

An interesting account of the establishment of the basing point system of deliv-

12 13 Report of the Industrial Commisston 469 (Igor).

${ }^{23}$ Wooden, The Defense of Delivered Price Systems, 15 Geo. Wash. L. REv. I, 31 (1946).

${ }^{14}$ A detailed record of the part played by the United States Steel Corporation in establishing the use of the basing point system for the sale of all steel products except rails may be found in Federal Trade Comm'n v. United States Steel Corporation, Docket No. 760, Statement of Case, Brief and Argument by Attorneys for the Federal Trade Commission, and Trial Examiner's Report on the Facts (1924). 
ered prices in the sale of bars and plates is contained in the following report written in Igor by a trade correspondent in Philadelphia: $:^{15}$

Early in the year it looked as though there might be a somewhat demoralized market for bars and plates, but this was fortunately avoided by the manufacturers of each of these specialties formulating plans for maintaining uniform prices, which have proved to be eminently successful. It took a good deal of time to arrive at a basis which would be satisfactory to all the various interests, one great difficulty being in the variety of conditions in regard to location of mill, proximity to markets, cost of production, etc. The plan finally adopted and which has worked perfectly so far, and which is likely to be continued indefinitely, was to base all quotations at a figure agreed upon for f.o.b. deliveries in Pittsburgh. The local mills (Philadelphia) therefore quote Pittsburgh pricesplus freights to whatever point the material has to be shipped. . . . The same plan is in force among the plate mills, although it is less binding than that in bars. The plate mills have a verbal agreement, and the bar mills have a written agreement which is further strengthened by a substantial cash deposit. The lowest prices during the year were $\$ 1$. 35 for bars and $\$$ I.40 for plates, but under the price agreement they are now $\$ 1.62$ and $\$ 1.72$, and likely to remain at that for an indefinite period.

Shortly after the general adoption of the basing point plan in the iron and steel industry in Igor, the practice was extended to the cement industry. ${ }^{16}$ Thereafter, the plan had little vogue until around IgI2 when its use became widespread. Products, in addition to iron and steel, which came to be sold on a single basing point plan were cast-iron soil pipe, glucose, malt, maple flooring, welded chain, zinc, lead (St. Louis plus freight differentials), and copper ("Connecticut Valley" plus freight differentials). Certain industries adopted a multiple basing point system in which two or more basing points were established by industry leaders for pricing purposes. Representative products which came to be sold on a multiple basing point plan were cement, iron and steel (after 1924), hardwood lumber, gasoline, sugar, chemical fertilizers, milk and ice cream cans, asphalt roofing materials, linseed oil, rigid steel conduit, fire brick, lubricating oil, and plate glass.

\section{III}

\section{The Basing Point Formula}

\section{A. A Form of Cooperative, Systematic Price Discrimination}

The essence of the basing point formula (in contrast with f.o.b. mill pricing) is the sale of goods at delivered prices which are determined by quoting the base price of some other mill plus freight from that mill to destination. In so far as a mill quotes its own mill price, uniform to all customers, it is engaging in f.o.b. mill pricing. Basing point pricing comes into existence when geographically separate

\footnotetext{
${ }^{10}$ The Philadelphia Iron Market for igot, Annual Review of the New York Metal Exchange 3 (1902).

${ }_{10}$ FTC, Price Bases Inquiry: The Basing Point Formula and Cenent Prices 29-4I (1932). In 1948 the Supreme Court held that the Federal Trade Commission was fully justified in finding "understanding expressed or implied" in the establishment and use of the multiple basing point system in the cement industry. Federal Trade Comm'n v. Cement Institute, 333 U. S. 683, 716 (1948).
} 
mills quote delivered prices for any destination by adding to an established base price at a given point, called the basing point, the freight charge-usually rail freight-from that point to the point of delivery, regardless of the actual origin of shipments or the actual freight cost incurred. As a general rule, it may be said that the selection of a base price is made by a price leader (a dominant corporate merger). ${ }^{17}$ The base price or prices so established are thereupon accepted (with rare exceptions) by all other mills for making sales in the contiguous territory.

The various mills in a basing point industry may employ one or more bases for the entire country, and in some industries every mill may serve as the base mill for its contiguous territory. The practice of charging a customer the freight cost which he would pay in getting delivery from a nearer supplier rather than the seller's actual transportation cost, is known as freight equalization. In a plan of freight equalization every mill is usually regarded as a base.

The price relationships which arise in multiple basing point selling are illustrated in Fig. I. A, B, and C, it may be assumed, are sugar mills selling in their own localities, as well as in the principal consuming center of $B$. A and B are base mills, and $\mathrm{C}$ is a non-base mill. Under the multiple basing point system each seller quotes

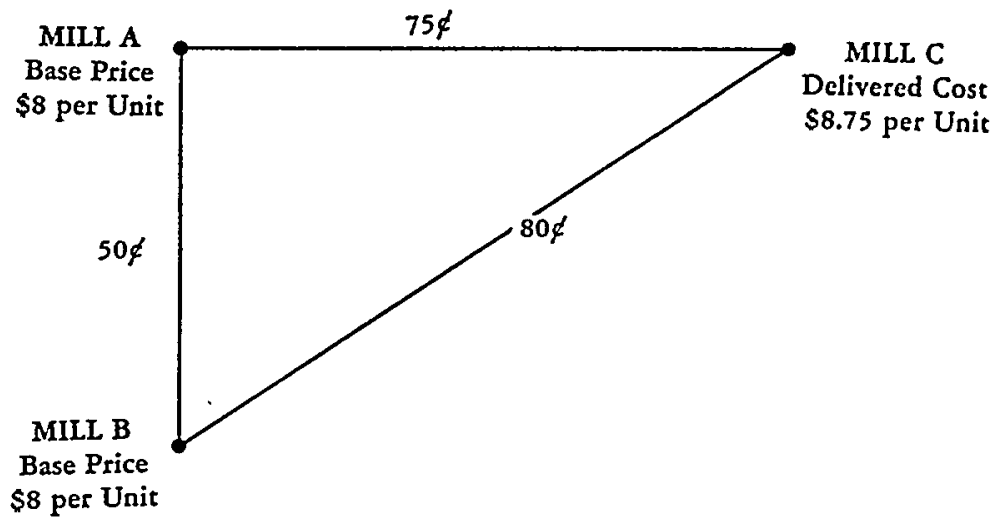

FIG. I. The multiple basing point system of delivered prices. All mills regularly quote the particular "base price" plus freight from the basing point to the customer's location which gives the lowest combination of base price and freight cost. The essence of the basing point plan is the use of the base price and freight of some other mill.

a delivered price which is the lowest combination of a base price at any base mill plus the rail freight from that mill to a particular destination. Thus all buyers at $\mathrm{C}$ are given an identical delivered price quotation of $\$ 8.75$ per unit. Mill C, it may be noted, charges its local customers a freight item of 75 cents per unit which it does not pay out in making delivery. This fictitious charge is known as "phantom freight." Phantom freight may be defined as the excess of the freight item charged the buyer over the freight actually paid out by the seller in making delivery. The "justification" which business interests usually give for phantom freight is the asser-

${ }^{17}$ Brief for Respondents, Vol. I, App. A, pp. 474-476; Federal Trade Comm'n v. The Cement Institute, 333 U. S. 683 (I948). 
tion that the price of $\$ 8.75$ per unit is the price which a buyer at $\mathrm{C}$ would have had to pay for sugar if someone had not chosen to build a factory at $\mathrm{C}$.

On sales in $B$ all buyers are given an identical delivered price quotation of $\$ 8.00$ per unit. This pricing practice means that mills $A$ and $C$ have their mill net prices reduced 50 cents and 80 cents respectively by "freight absorption." Freight absorption is defined as the excess of the actual freight paid in making delivery over the amount of the freight item used in calculating the delivered price.

The absorption of variable amounts of freight on current sales (as well as the charging of variable amounts of phantom freight) results in variable mill net prices. In the Staley case ${ }^{18}$ price discrimination was considered by the Supreme Court to be the making of a difference in the net amount charged to different buyers by any seller. This view of discrimination is in accord with the concept of discrimination employed in economic analysis. The price discrimination involved in the basing point system was said by the Court to be regular and systematic. The discrimination is regular and systematic because (I) all geographically separate mills regularly quote the delivered price of the appropriate base mill and (2) they absorb (or add) just enough freight (no more and no less) to match the base price plus the rail freight from the basing point to the customer's location.

\section{B. The Exclusion of Independent Merchants and Distributors}

The adoption of basing point pricing has involved the use of two additional restrictive sales methods. A consideration of these factors, unfortunately, has largely been overlooked in current discussions of the basing point problem. The first is the concerted practice of basing point mills to refuse to sell to independent merchants and distributors. In their efforts to manage prices the large combinations soon found that supplies in the hands of middlemen and dealers directly limited their power to raise prices as consuming demands increased. Independent merchants typically accumulated large inventories of basic commodities-such as pig iron, merchant bars, copper, lead, and zinc-during periods of low prices and slack demand, for sale when fabricating industries resumed their buying. This activity helped to maintain an even state of employment and production. The combinations, however, found that the presence of accumulated supplies in independent hands not only limited their ability to get higher prices during a period of business expansion, but also provided a source of competition over which they had no control.

In order to eliminate the troublesome competition of independent distributors, all of the large steel producers soon after Igor opened their own district sales offices and assumed an almost complete control over the distribution of their iron and steel products. Local jobbers were permitted to stock a few products-such as horseshoes, nails, galvanized sheets, and fencing-for local sale and usually at prices higher than the delivered carload rate. Such jobbers, however, were sold only a few carloads at a time, and speculative buying was not permitted.

${ }^{18}$ Fcderal Trade Comm'n v. A. E. Staley Mfg. Co., 324 U. S. 746, 75I (1945). 
The combinations in the non-ferrous metals industry similarly sought to strengthen their use of basing point pricing by adopting the policy of selling only to consumers (fabricators). Soon after rgor the lead combination adopted the policy of selling refined and common pig lead only to consumers, and in quantities which it believed they should purchase. This industry policy has been continued to date. The primary producers of copper likewise adopted a general policy of refusing to sell to dealers or speculators. Their declared reasons for this policy are (I) to discourage trading on the commodity exchanges and (2) to prevent dealers from acquiring supplies for sale again when consumer demands are rising. ${ }^{10}$ In a program of stabilizing zinc prices, the major zinc producers in 1928 established East St. Louis as the basing point for Prime Western slab zinc and uniformly restricted sales of zinc to consumers. ${ }^{20}$

In the development of the cement industry the usual marketing policy was one of selling through distributors and other wholesale middlemen at f.o.b. mill prices. A witness for the industry in the recent Cement case, for example, stated, "In the early days of the distributor relationship the sales were at f.o.b. mill prices. The commitments from the distributors to ourselves were definite commitments and the distributor was at perfect liberty and did sell as he could, for whatever measure of profit he could get." ${ }^{21}$ The elimination of the independent merchants in the cement industry, and the discontinuance of making all sales f.o.b. the mill took place in various regions from 1902 to $1912 .{ }^{22}$ As in the case of iron, steel, and the non-ferrous metals, the elimination of the cement merchants by a combination or industry group occurred quite abruptly. An industry witness in the Cement case, for example, testified, "We eliminated most of them at the end of $1902 . " 23$

The results of "fencing in" the demand for iron and steel, the non-ferrous metals, and many other basic commodities have been more far reaching than is generally realized. Merchants and speculators bought supplies when consumer demand was declining and sold them again when business improved. This activity helped to provide first-hand producers with a continuous market and also served to stabilize prices. In restricting the sale of their products to fabricators, processors, and local jobbers, the large combinations have created a condition in which there is little, if any, current demand whenever the consuming industries are not buying. The demands of consuming industries, moreover, are usually quite irregular, for they reflect the variable demands of ultimate consumers and the general state of business. By "fencing in" the demands for their products, basing point industries have accentuated the problem of providing sustained employment and production.

\footnotetext{
${ }^{10}$ Hearings before Temporary National Economic Committee on P. Res. 113, Pt. 25, 76th Cong, 3d Sess. 13244-13245 (r940).

20 Vernon A. Mund, Open Markets 199-201 (1948).

21 Brief for Appellants, Vol. I, App. A, p. 105, The Cement Institute v. Federal Trade Comm'n, I44 F. 2 d 221 (C. C. A. 7th 1945).

${ }^{22}$ Id. at I04-II5.

${ }^{23}$ Id. at III.
} 
In 1899 the tin-plate workers of Pittsburgh called attention to the serious impact on employment of the newly established policy of the tin-plate combination to restrict sales to consuming buyers of its own choice. According to the union, "When the trade was in the hands of independent firms, large quantities of ware were manufactured into stock against future calls or sold at very small profits to large buyers who stocked it in their own warehouses against the brisk season; thus the workmen were given employment throughout the slack winter months. But the trust, having complete control of the trade, will neither incur the cost of storage on its own premises nor abate its ironclad prices so that the buyers may lay up a stock for future trade."24

\section{Price Management and the Curbing of Production}

A second restrictive policy which the large combinations adopted in conjunction with basing point pricing was that of producing only those quantities which could be sold at the managed prices. The general practice of independent mills prior to the formation of monopolistic mergers was to produce continuously, in good times and bad, for sale to a variety of trade interests-merchants, speculators, fabricators, and industrial users. When the level of business activity declined, it was the inefficient, poorly located mills which discontinued their operations. At no time, it appears, was there a general curtailment of production by all mills-efficient and inefficient. With the formation of mergers, however, the production of all mills was typically curbed to prevent an accumulation of supplies and a "breaking" of prices. The large combinations could and did sharply restrict the output of their own mills, and the remaining independents soon adopted a similar policy. Since the established plan was one of refusing to sell to nonconsuming interests, a producing mill either had to find customers at the "official" prices or store its products in its own warehouses. Most mills did not-and do not-have large storage facilities. The practical alternative, therefore, became one of restricting output and employment rather than of producing for inventory.

The hearings of the Federal Trade Commission on basing point pricing in the cement industry showed clearly that the limited storage facilities possessed by firsthand producers are a barrier to continuous employment. Industry members repeatedly stated that the storage facilities of most plants are insufficient for continuous production. ${ }^{2 \bar{v}}$

IV

The Freight Allowed or Zone Delivered Pricing System

\section{A. History and Operation}

A second type or form of delivered pricing is the "freight allowed" or "zone delivered" method of price quotation. When this method of pricing is used jointly

24 I Report of the Industrial Commission 905 (190r).

25 Brief for Appellants, Vol. I, App. A, p. 79, The Cement Institute v. Federal Trade Comm'n, I44 F. $2 \mathrm{~d} 22 \mathrm{r}$ (C. C. A. 7 th 1945 ). 
by two or more sellers (either by agreement or by price following), it also results in identical delivered prices and an avoidance of price competition.

The first use of the freight allowed method of pricing appears to have come with the formation of the American Tobacco Company in 1890 . During the period 1890 to Igoo the plan was extended to the sale of such products as water meters, wire rope, retail scales, meat slicers, and meat choppers. From Igoo to I904 pipe tools, vises, pipe cutters, auger bits, wood boring tools, screw drivers, and machine knives were priced "freight allowed." From I908 to I9I2 the practice was adopted by manufacturers of automobile tires, tire chains, brake lining, various chemical products, and electric lamps. Many additional industries adopted freight allowed methods of selling during the National Recovery Administration (1933-r935), and new applications have been made up to the present time.

In using the freight allowed method of pricing, a seller quotes a base or zone price containing an average freight item and thereupon "allows" the freight from his mill to destination. The goods may be sent prepaid or the buyer may be directed to pay the freight and deduct it from the invoice cost before remitting payment. In certain cases, the practice is for a seller (or industry group) to establish a national uniform delivered price applicable to any established freight station in the United States. This is the basis on which the Post Office Department carries the mail. In other cases the country is divided into two or more geographical areas or zones, and a uniform delivered price (including a transportation increment averaged for the zone) is quoted for each zone.

A classification of the various methods of selling products "freight allowed" may be made as follows $:^{26}$

I. Goods sold at one list or base price for the entire country with a full allowance of freight to any established freight station. A minimum shipment may or may not be specified. Examples of products sold by this method include-

Arc Welding Machines

Tire Chains (24 pairs)

Brake Lining ( 100 lbs.)

Multi-blade Fans, Blowers, and Air Washers

Houschold Electrical Appliances

Files and Rasps (150 lbs.)

Machine Knives

Rubber soled Canvas Footwear (100 lbs.)

Lubricated Plug Valves (500 lbs.)

Steel Split Pulleys

Copper Wire (insulated or plain), Cable, Sheets, and Tubing (200 lbs.)

Brass and Bronze Wire or Cable (200 lbs.)

Mechanics' Hand Tools

Flexible Steel and Aluminum Conduit (xoo lbs.)

Bakelite

Rubber Fuel Tanks

Rubber Cement
Aluminum Products (500-1,000 lbs.)

High-grade Zinc

Mechanical Rubber Goods (100 lbs.)

Leather Transmission Belting (roo lbs.)

Steam Condensors (traps)

Sheet Metal Fittings ( $\$ 200$ )

Asbestos Products

Water Meters (I50 lbs.)

V-Drive Pulleys and Belts (roo lbs.)

Pneumatic Tools and Hoists

Stillson Pipe Wrenches (200 lbs.)

Air Compressor Hose (500 ft.)

Rubber and Fabric Transmission Belting (100 lbs.)

Chain Hoists (Hand operated), Trolleys, and Winches (roo lbs.)

Marine Specialties and Ship Fixtures (100 lbs.)

Soft Drinks

20 The examples of products sold at zone delivered prices are from a survey made by the writer in 1949. This survey was undertaken for a fortheoming book, Government and Business, to be published in the spring of 1950. 
2. Products sold at one list or base price for the entire country with "freight allowed and prepaid" to any established freight station. Representative products sold by this method include-

\section{Cadmium}

Industrial Motors and Controllers

Electric Lamps (standard packages)

Biologicals, Arsenicals, Insulin, and other drug specialties

Coated Abrasives (200 Ibs.)

Rubber Covered Building Wire

Cable Accessories and Magnet Wire (Ioo lbs.)

Dictating Machines and Accessories

Typewriters

Glazier Tools (100 lbs.)
Groceries; Trade-marked items-such as soap, canned soup, shortening, cereals, cake flour, and canned dog food (I carload)

Automobile Tires and Tubes (200 lbs.)

Cash Registers, Accounting Machines, Adding Machines, and Check Writing Machines.

Notions-such as zippers, buttons, pins (Variable minimums)

Cotton Thread (roo lbs.)

Cigarettes and Tobacco Products

Candy Bars (roo lbs.)

3. Products sold to dealers and industrial users with "freight allowed" or "allowed and prepaid" within zones. Representative products include-

Arc Welding Electrodes (roo lbs.)

Hard Fiber Twine

Insulating Board Products

Water Works Valves

Scales, Meat Choppers, Slicers, and Coffee Mills

Power Cable

Street Lighting Equipment, Reactors, Feeder Regulators (100 lbs.)

Distribution Transformers

Portable Air Compressors

Portable Elevators

Glass Containers

Brass and Copper Strip (roo lbs.)

Paint

Screws, Nuts, Bolts

Elcctric Grinders

Gasoline Service Station Pumps
Lubricating Oil, Grease, and Kerosene Dispensing Equipment

Hydraulic Lifts (Gasoline Station)

Sash Pulleys (roo lbs.)

Folding Chairs and School Chairs

Chain, Sprockets, Gears, and Power Transmission Machinery (roo lbs.)

Wire Rope (200 lbs.)

Liquid Chlorine

Feed Water Heaters

Cross Cut Saws and Handles, Hack Saw Blades and Frames, Hand Saws, and Saw Tools (roo lbs.)

Lye

Hand Lift Trucks

Paper Bags

Water Softeners

4. Products sold to local jobbers and distributors with freight allowed to designated distribution points. Representative products include-

Portable Electric Tools (I0o lbs.)

Various Chemical Products

Air Rifle Shot (200 lbs.)

Oil Cans, Oilers, Fillers, and Torches

Electric Fans (100 lbs.)

Plumbing Fixtures (carload lots)

Ammunition

Kraft Paper and Kraft Container Board

Firearms (100 lbs.)

Dry Cell Batteries and Flashlights (200 lbs.)

Pliers, Wrenches, and Small Tools (roo lbs.)

Rock Drills (roo lbs.)

Auger Bits, Wood Boring Tools, and Screw Drivers (\$I00)

Manila Rope (200 lbs.)

Road Machinery

Ladders

Brass and Copper Products

\section{B. Reasons for the Use of the Freight Allowed Policy}

The freight allowed method of price quotation may be used independently and individually by a given seller for any one of a number of reasons. Some sellers report that they desire to have a uniform national retail price for advertising purposes and at the same time give their variously located retailers the same delivered cost. This is accomplished by including an average freight item in the quoted price. Other manufacturers report that they desire to place their wholesale distributors in adjoining territories on "an equal competitive basis." Some firms state that they employ a zone pricing system in order to secure lower delivered costs on sales into distant 
areas. By averaging the freight item, the seller can hold delivered costs in other areas to a lower level.

Although zone delivered pricing methods may be used independently, the evidence indicates that they are often employed by an entire industry group. With the systematic practice of full freight allowance and with identical factory (or base) prices, the plan serves as an effective method for securing identical delivered prices. Each locally separate seller simply adopts the base or zone price announced by the dominant seller or sellers with the proviso "freight allowed" or "freight allowed and prepaid," and all buyers at a given destination point are thereupon given the same quotation. (See Fig. 2.)

$\begin{array}{cc}\text { MILL A } & \text { \$1.00 Freight } \\ \begin{array}{c}\text { Base or Zone Price \$20 } \\ \text { (Freight Allowed) }\end{array} & \text { Base or Zone Price \$20 } \\ \text { (Freight Allowed) }\end{array}$

Fig. 2. The freight allowed or zone delivered system of pricing. Each seller following the formula adopts an identical base or zone price (containing an average freight item) and "allows" the freight from his mill to the destination. Buyers at all destination points, accordingly, are given the same price quotation.

\section{Practices Used by Dominant Sellers to Secure the Observance of Delivered Pricing Formulas}

During periods of declining demand, independent mills (usually single plant competitors) are frequently tempted to deviate from the use of delivered pricing formulas on sales in certain areas or to certain customers in an effort to secure an outlet for their products. There is abundant evidence to show that the price leader (or leaders) usually takes immediate steps to correct this situation. One method used is to talk with the recalcitrant mill about the dangers of sporadic and cutthroat discrimination. The general counsel for the United States Steel Corporation, for example, has advised his client that "The harmful effects of cutthroat competition, of unfair trade methods, of selling below cost or even a fair margin of profit, and the like, are legitimate subjects of discussion."27 'The fear of discriminatory pricing practiced by large concerns is still a powerful motive which serves to secure and maintain compliance.

A common method employed by industry leaders to maintain the observance of basing point systems is that of imposing a "punitive base price" on the competing mill which is equal to the lowest mill net price received by the competing mill. In using this technique, a price leader quotes a low base price in the area of the rival ${ }^{27} \mathrm{Hedi}$ (1939). 
mill to govern all sales made in that area. This practice means that the low price made by the rival mill for a few sales will prevail on all local sales. ${ }^{28}$

Another practice employed by an industry leader to secure compliance with delivered pricing systems is that of "price raiding." Price raiding means the "cutting" of delivered prices in particular local areas, or to particular customers, usually in a discriminatory way, expressly to injure the concern showing a price independence. The resulting price chaos is known as a "price war." The power of a dominant concern to cut prices to extremely low levels is based either upon financial strength or upon the existence of monopoly power in certain areas in which the losses may be recouped. ${ }^{20}$

The privilege of using discriminatory pricing methods (especially sporadic geographic discrimination) gives industry leaders a powerful weapon of coercion and discipline for securing unity of action on price. A further factor accounting for unity of action is the extra profits which all sellers may secure through an avoidance of price competition. As a result of the factors of fear and favor, every follower acts in a restrained manner as if he were forbidden to reduce the delivered prices required by the industry formula. Upon the basis of this consistent mutuality of behavior, various economists, the Federal Trade Commission, and the courts have concluded that the collective or parallel use of basing point or zone delivered pricing systems involves either agreement or a mutual restraint on individual action with illegal trade restraining effects.

\section{Delivered Pricing Systems and Industrial Decentralization}

Basing point and zone delivered pricing systems operate not only to eliminate price competition, but also to prevent a decentralization of industry. The use of an eastern base price makes for high cost-prices in the West and South and discourages the development of local fabricating industries. Local fabricators which do develop, moreover, cannot ship eastward to any significant extent in competition with fabricators located near an eastern basing point, because the delivered costs of their basic supplies are higher.

When basic products (such as aluminum) are produced in the West and South and sold "freight allowed," the development of local fabricators is likewise restricted. Local prices are high-as high as elsewhere in the country-and fabricators find no cost advantage in building plants near the sources of supply. The sale of fabricated products (such as copper wire, cable, and tubing) by eastern mills at freight allowed prices (based upon an average freight item) also serves to discourage the develop-

${ }^{28}$ Data on the use of punitive base prices to discipline industry members showing a price independence may be found in Brief for Appellees, Vol. I, App. A, pp. 495, 499, 504-505, Federal Trade Comm'n v. The Cement Institute, 333 U. S. 683 (1948).

${ }^{20}$ Corwin D. Edwards cites the case of a large producer in the building materials industry which has carried a cash reserve of over Io million dollars for use as a "war chest" to discipline rivals who reduce prices below levels which the company regards as satisfactory. Edwards, Maintaining CompeTITION 169-Ijo (I949). 
ment of distant fabricators, for the established mills, in effect, are able to "dump" into the distant areas by absorbing some or all of the freight-at the expense of their nearby customers.

\section{VII}

\section{Some Conclusions on the Use of Basing Point and Zone Delivered Pricing Systems}

Historical data show that with the rise of markets in the American economy, industrial and agricultural products were typically sold at f.o.b. prices. Subsequently, with the rise of mergers, basing point and zone delivered pricing systems were increasingly adopted by multiple-plant producers in order (I) to insure identical delivered prices and (2) to avoid the automatic allocation of sales which f.o.b. mill pricing would involve. In general, independent producers were given the opportunity of following the leader on price. A policy of price following was usually adopted in order (I) to secure extra profits or (2) to eliminate the instability of sporadic discrimination. Delivered pricing systems were widely adopted during the period of the National Recovery Administration when the application of the antitrust laws was suspended.

Basing point and zone delivered pricing systems are only two of several special devices of restriction employed by monopolistic groups. Other important and concomitant devices are ( $\mathrm{I}$ ) the concerted refusal of organized producers to sell to independent dealers and distributors and (2) the curbing of production to those quantities which can be sold at the managed prices.

Basing point and zone delivered pricing systems work an injury to buyers because (I) they force some buyers to pay an overcharge for freight; (2) they deny all buyers the privilege of arranging for the purchase of their own transportation; and (3) they usually result in an elimination of independent price competition.

Local price cutting-cutthroat and sporadic-is a principal means by which dominant firms coerce, injure, and discipline geographically separate independents. At the present time, the use of cutthroat competition has largely been replaced by that of sporadic or anarchic discrimination practiced to limit a competitor rather than to destroy him.

Spokesmen for big business frequently attempt to justify sporadic price discrimination by declaring that this method of pricing promotes competition. In absorbing all or a part of the freight charges, it is said, sellers can acquire business in distant markets and buyers are given a wider choice of sellers. The fact is, however, that sporadic discrimination is only a limited kind of competition-restricted to certain areas. It is not the kind of competition found in open markets.

Experience has shown, moreover, that sporadic discrimination usually works to the disadvantage of small, single-plant competitors. When a small business firm is getting established in a particular area, it frequently finds that it must offer its goods at prices somewhat below those of a large rival. Its prestige and reputation are not 
firmly established, and some inducement must be offered to secure customers. If a large distant concern is permitted to match the local prices by reducing its mill net prices on sales in that area, the small rival may have little opportunity of ever developing its business.

Neither economists nor lawyers have thus far been able to develop a workable rule or standard for use in permitting the exercise of freight absorption, except by reference to the exclusion of competitors. Where can the line be drawn between legitimate and illegitimate degrees of geographic price discrimination? Must an efficient producer wait for relief until he has been forced into bankruptcy? If a mill shrinks its mill net to ship into a distant area and regularly matches the price which it finds, it is following a plan of systematic price discrimination. This is the monopolistic basing point practice. On the other hand, if a mill quotes a discriminatory delivered price which is below that of a rival in the distant area, it is a case of local price cutting which Section 2 of the Clayton Act was expressly designed to prevent.

There is no logical basis for legalizing price discrimination which is exercised "in good faith to meet competition." As applied to geographic price discrimination, the term "meeting competition" means the cutting of net prices to buyers in a certain area while maintaining them on sales made in other areas. Meeting competition, in this sense, is the very act of discrimination. In real markets (local, central, or primary), sellers do not "meet competition" by engaging in price discrimination.

The phrase "in good faith to meet competition" has no established or generally accepted economic or legal meaning. A consideration of "motives" is a task for mind readers and clairvoyants rather than for administrative agencies and the courts. All business is done for commercial advantage; and the task of supervising a policy of legalized geographic price discrimination would impose an exceedingly difficult burden upon the antitrust agencies.

An important reason for going further in the direction of required f.o.b. mill pricing is to try to get behavior which is like that found in competitive markets. With the collective use of basing point and zone delivered pricing systems, sellers do not have a motive-a competitive pressure or compulsion-to reduce base prices in order to provide a selling outlet for their capacity. When business begins to decline, a basing point or freight allowed practitioner reaches out for customers by absorbing larger amounts of freight. The extent to which he reduces his mill net by absorbing freight depends upon how "hungry" he is for business. As a result of this practice, a seller secures lower net prices on a part of his sales, but delivered prices to buyers are usually not reduced. An abolition of freight absorption would do much to correct this situation. Locally separate mills would be provided with a genuine motive to reduce their base prices in order to sell in distant consuming areas, and the resulting price flexibility would insure a more rapid adaptation of the economy to changes in the conditions of demand and supply. 
F.o.b. mill pricing is only a partial remedy for the problems of geographic price discrimination and identical delivered pricing, for the factors of collusion, conspiracy, and monopolistic mergers still remain. If the substance of the problem of industrial monopoly in the United States is to be reached, consideration must be given to centralized financial control and corporate concentration. ${ }^{30}$

${ }^{30}$ See, particularly, the remedies proposed by Corwin D. Edwards, id. at $\times 33-155$. 